\title{
Hydroxylated PCB Derivatives. Synthesis and Structure Elucidation by NMR Spectroscopy and X-Ray Diffraction
}

\author{
Erkki Mannila, $^{\dagger, a}$ Erkki Kolehmainen $^{\mathrm{b}}$ and Kari Rissanen ${ }^{\mathrm{c}}$
}

\author{
${ }^{a}$ Department of Pharmaceutical Chemistry, University of Kuopio, P.O.B. 1627, FIN-70211 Kuopio, Finland, ${ }^{b}$ University of \\ Jyväskylä P.O.B. 35, FIN-40351 Jyväskylä, Finland and ${ }^{\mathrm{C}}$ Department of Chemistry, University of Joensuu P.O.B. 111 , \\ FIN-80101, Joensuu, Finland
}

\begin{abstract}
Mannila, E., Kolehmainen, E. and Rissanen, K., 1994. Hydroxylated PCB Derivatives. Synthesis and Structure Elucidation by NMR Spectroscopy and X-Ray Diffraction. - Acta Chem. Scand. 48: 684-688 (1) Acta Chemica Scandinavica 1994

Structures of eight PCB derivatives: 2',3,4',5',6-pentachloro-2-biphenylol (1), $2,2^{\prime}, 4^{\prime}, 5.5^{\prime}$-pentachloro-3-biphenylol (2), 2,2', $4^{\prime}, 5,5^{\prime}$-pentachloro-4-biphenylol (3), 2', 4, 4',5,5',6-hexachloro-2-biphenylol (4), $2^{\prime}, 3^{\prime}, 4,4^{\prime}, 5,6,6^{\prime}$ '-heptachloro-2-biphenylol (5), $2,2^{\prime}, 3^{\prime}, 4,4^{\prime}, 5,5^{\prime}$-heptachloro-3-biphenylol (6), $2,2^{\prime}, 3,3^{\prime}, 4^{\prime}, 5,5^{\prime}$-heptachloro-4-biphenylol (7) and $2^{\prime}, 3^{\prime}, 4,4^{\prime}, 5,5^{\prime}, 6,6^{\prime}$-octachloro-2-biphenylol (8) have been slucidated by use of ${ }^{1} \mathrm{H}$ NMR chemical shift assignment of 1-8, a heteronuclear ${ }^{13} \mathrm{C}-{ }^{1} \mathrm{H}$ chemical shift correlation spectroscopy (C,H-COSY) experiment on 1, mass spectra and high resolution mass spectra of 1-8 and X-ray crystallographic analysis of $\mathbf{4}$ and $\mathbf{8}$. All compounds were synthesized by a modification of the aromatic arylation method of Cadogan by coupling the corresponding chloroaniline and chloroanisole in the presence of isoamyl nitrite, followed by demethylation with boron tribomide in $\mathrm{CH}_{2} \mathrm{Cl}_{2}$. Compound 4 crystallizes in the monoclinic space group $P 2_{1} / n$ (No. 14$)$ with cell dimensions: $a=8.988(2)$, $b=19.490(3)$ and $c=10.722(2) \AA$ and $V=1813.8(5) \AA^{-3}$ with $Z=4$. Full-matrix least-squares refinement of 208 parameters gave $R=0.048$ for 2195 reflections $[I>3 \sigma(I)]$. Compound 8 crystallizes in the triclinic space group $P 1$ (No. 2) with cell dimensions: $a=8.440(2), b=7.726(2)$ and $c=13.328(3) \AA$ and $V=780(1) \AA^{-3}$ with $Z=2$. Full-matrix least-squares refinement of 190 parameters gave $R=0.057$ for 1551 reflections $[I>3 \sigma(I)]$.
\end{abstract}

Polychlorobiphenyls (PCBs) are among the most widespread man-made chemicals in the world. Their chemical persistence and lipophilic nature, causing bioaccumulation in higher trophic levels, including man, together with the very high toxicity of some of their congeners is causing risk to humans and wildlife.'

The oxidation and metabolism of PCBs in organisms have been observed to produce hydroxylated polychlorobiphenyls, ${ }^{2-11}$ which have also been found, for example, in human blood. ${ }^{12}$ Hydroxychlorobiphenyls have been detected among the pyrolysis products of PCBs ${ }^{13}$ and a number of them have been synthesized. ${ }^{4,6,7,14,15}$

The precise stereostructure elucidation is necessary in determining the quantitative structure-activity relationships (QSAR) of environmentally important chlorinated aromatics. ${ }^{16.17}$ NMR spectroscopy combined with mass spectrometry and X-ray diffraction forms a powerful structure specific method to study such compounds. ${ }^{1} \mathrm{H}$ NMR and ${ }^{13} \mathrm{C}$ NMR spectroscopy is usually the major method to achieve isomer specificity in determining the structures of environmentally important substances such

\footnotetext{
† To whom correspondence should be addressed.
}

as chlorinated biphenyls, chlorobiphenylols and chlorinated dibenzothiophenes. ${ }^{15,18-21}$ In addition, vicinal and long-range ${ }^{1} \mathrm{H}$ and ${ }^{13} \mathrm{C}$ NMR coupling constants exhibit well-known angular dependencies. These parameters can be useful in estimating the conformational preferences such as the coplanarity of the rings in PCBs, which has been considered to be the major factor affecting the physiological activity of these compounds. ${ }^{22}$

\section{Experimental}

Preparation of the compounds. All compounds were synthesized by a modification of the aromatic arylation method of Cadogan..$^{23-30}$ In the general procedure the mixture of chloroanisole and chloroaniline 10:1 (w/w) was warmed until it became liquid. Isoamyl nitrite was added dropwise into the reaction mixture; at the same time the temperature was slowly raised to $130^{\circ} \mathrm{C}$. When the reaction had subsided the excess of chloroanisole was removed by steam distillation. The undistilled material was extracted with $\mathrm{CH}_{2} \mathrm{Cl}_{2}$, which was smoothly treated with conc. sulfuric acid to remove the coloured 
impurities. Sulfuric acid was removed and the solvent was evaporated off. The products were further purified by flash chromatography: $25 \mathrm{~mm} \times 100 \mathrm{~mm} \mathrm{Al}_{2} \mathrm{O}_{3}$ column and $\mathrm{CH}_{2} \mathrm{Cl}_{2}$ as the eluent. For the demethylation a single or a mixture of methoxychlorobiphenyls was dissolved in $5 \mathrm{ml} \mathrm{CH}_{2} \mathrm{Cl}_{2}$. A small excess of $\mathrm{BBr}_{3}$ in $5 \mathrm{ml}$ of $\mathrm{CH}_{2} \mathrm{Cl}_{2}$ was added and the reaction mixture was refluxed until the reaction was complete. After the addition of ice-water the $\mathrm{CH}_{2} \mathrm{Cl}_{2}$ layer was separated, dried with $\mathrm{Na}_{2} \mathrm{SO}_{4}$, filtered and evaporated. In the case of isomeric mixtures the final separation was done for chlorobiphenylols by standard flash chromatography: $25 \mathrm{~mm} \times 100 \mathrm{~mm}$ Silica gel (mesh 230-400) column and $\mathrm{CH}_{2} \mathrm{Cl}_{2}$ as the eluent. The total yields were $1-5 \%$.

Preparation of compounds 1-3. The corresponding methoxypentachlorobiphenyls were prepared from 2,5-dichloroanisole and 2,4,5-trichloroaniline as described above. The three isomers formed were demethylated as a mixture and separated as hydroxybiphenyls by flash chromatography: $25 \mathrm{~mm} \times 100 \mathrm{~mm}$ Silica gel 60 (mesh 230-400) column and $\mathrm{CH}_{2} \mathrm{Cl}_{2}$ as the eluent. The elution order was 1,2 and 3.

$2^{\prime}, 3,4^{\prime}, 5^{\prime}, 6$-Pentachloro-2-biphenylol (1). ${ }^{1} \mathrm{H} \quad \mathrm{NMR}$ $\left(270.13 \mathrm{MHz}, \mathrm{CDCl}_{3}\right): \delta 5.700(\mathrm{OH}, \mathrm{s}), 7.093(\mathrm{H} 4, \mathrm{~d}, J$ $8.67 \mathrm{~Hz}), 7.389(\mathrm{H} 5, \mathrm{~d}, J 8.67 \mathrm{~Hz}), 7.405$ (H3', d, $J$ $0.27 \mathrm{~Hz}), 7.678\left(\mathrm{H6}^{\prime}, \mathrm{d}, J 0.27 \mathrm{~Hz}\right) .{ }^{13} \mathrm{C}(67.8 \mathrm{MHz}$, $\left.\mathrm{CDCl}_{3}\right): \delta 149.2(\mathrm{C}-2), 132.8\left(\mathrm{C}-1^{\prime}\right), 132.8\left(\mathrm{C}-2^{\prime}\right), 132.5$ $\left(\mathrm{C}-4^{\prime}\right), 132.1\left(\mathrm{C}-3^{\prime}\right), 130.6\left(\mathrm{C}-5^{\prime}\right), 130.3\left(\mathrm{C}-6^{\prime}\right), 128.9$ (C4), 123.9 (C-1), 121.3 (C-5), 118.2 (C-3), (C-6) not observed (overlap). MS [EI $70 \mathrm{eV} ; \mathrm{m} / z$ (\% rel. int.)]: 346 (20), 344 (65), 342 (100), 340 (63), 308 (32), 306 (66), 304 (50), 274 (26), 272 (81), 270 (86), 243 (35), 241 (36), 207 (25), 171 (34), 135 (15), 121 (18), 120 (19), 86 (17), 85 (21), 73 (17); HRMS: obs. 339.8778, calcd. 339.8783.

2,2', 4',5,5'-Pentachloro-3-biphenylol (2). ${ }^{1} \mathrm{H} \quad \mathrm{NMR}$ $\left(270.13 \mathrm{MHz}, \mathrm{CDCl}_{3}\right): \delta 5.800(\mathrm{OH}, \mathrm{s}), 6.878(\mathrm{H} 4, \mathrm{~d}, J$ $2.42 \mathrm{~Hz}), 7.165(\mathrm{H6}, \mathrm{d}, J 2.42 \mathrm{~Hz}), 7.400\left(\mathrm{H}^{\prime}, \mathrm{d}, J\right.$ $0.32 \mathrm{~Hz}), 7.645\left(\mathrm{H}^{\prime}, \mathrm{d}, J 0.32 \mathrm{~Hz}\right)$. MS [EI $70 \mathrm{eV} ; \mathrm{m} / z$ (\% rel. int.)]: 346 (23), 344 (72), 342 (100), 340 (70), 272 (29), 270 (31), 243 (18), 241 (19), 207 (17), 171 (25), 135 (16); HRMS: obs. 339.8778, calcd. 339.8783.

2,2', 4',5,5'-Pentachloro-4-biphenylol (3). ${ }^{1} \mathrm{H} \quad \mathrm{NMR}$ $\left(270.13 \mathrm{MHz}, \mathrm{CDCl}_{3}\right): \delta 5.730(\mathrm{OH}, \mathrm{s}), 7.220(\mathrm{H} 6, \mathrm{~d}, J$ $0.32 \mathrm{~Hz}), 7.261(\mathrm{H} 3, \mathrm{~d}, J 0.32 \mathrm{~Hz}), 7.400\left(\mathrm{H} 3^{\prime}, \mathrm{d}, J\right.$ $0.33 \mathrm{~Hz}), 7.631\left(\mathrm{H}^{\prime}, \mathrm{d}, J 0.33 \mathrm{~Hz}\right)$. MS [EI $70 \mathrm{eV} ; \mathrm{m} / \mathrm{z}$ (\% rel. int.)]: $346(23), 344$ (71), 342 (100), 340 (68), 272 (31), 270 (32), 243 (20), 241 (21), 207 (11), 171 (22), 135 (13); HRMS: obs. 339.8779 , calcd. 339.8783 .

$2^{\prime}, 4,4^{\prime}, 5,5^{\prime}, 6$-Hexachloro-2-biphenylol (4). Prepared from 3,4,5-trichloroanisole and 2,4,5-trichloroaniline as described above. ${ }^{1} \mathrm{H}$ NMR $\left(270.13 \mathrm{MHz}, \mathrm{CDCl}_{3}\right): \delta 6.290$ $(\mathrm{OH}, \mathrm{s}), 7.132$ (H3, s), 7.398 (H3', d, J 0.29 Hz), 7.692 $\left(\mathrm{H}^{\prime}, \mathrm{d}, J 0.29 \mathrm{~Hz}\right)$. MS [EI $70 \mathrm{eV} ; m / z$ (\% rel. int.)]: 380
(33), 378 (78), 376 (95), 374 (49), 342 (34), 340 (49), 338 (31), $308(48), 306(100), 304(80), 277(20), 275(16), 243$ (18), 241 (21), 207 (16), 205 (23), 171 (14), 138 (16), 121 (15); HRMS: obs. 373.8384 , calcd. 373.8393.

$2^{\prime}, 3^{\prime}, 4,4^{\prime}, 5,6,6^{\prime}$-Heptachloro-2-biphenylol (5). Prepared from 3,4,5-trichloroanisole and 2,3,4,6-tetrachloroaniline as described above. ${ }^{1} \mathrm{H}$ NMR $\left(270.13 \mathrm{MHz}, \mathrm{CDCl}_{3}\right): \delta$ $4.990(\mathrm{OH}, \mathrm{s}), 7.058(\mathrm{H} 3, \mathrm{~s}), 7.631\left(\mathrm{H}^{\prime}, \mathrm{s}\right)$. MS [EI $70 \mathrm{eV} ; m / z$ (\% rel. int.)]: $416(17), 414(52), 412(97), 410$ (100), 408 (46), 374 (10), 344 (17), 342 (52), 340 (79), 338 (49), 311 (18), 277 (22), 275 (18), 241 (19), 239 (19), 205 (17), 107 (15); HRMS: obs. 407.8000 , calcd. 407.8004.

Preparation of compounds 6 and 7. The corresponding methoxyheptachorobiphenyls were prepared from 2,3,6trichloroanisole and 2,3,4,5-tetrachloroaniline as described above. The two isomers formed were demethylated as a mixture and separated as hydroxybiphenyls by flash chromatography: $25 \mathrm{~mm} \times 100 \mathrm{~mm}$ Silica gel 60 (mesh 230-400) column and $\mathrm{CH}_{2} \mathrm{Cl}_{2}$ as the eluent. The elution order was 6 and 7.

2,2',3',4,4',5,5'-Heptachloro-3-biphenylol (6). ${ }^{1} \mathrm{H}$ NMR $\left(270.13 \mathrm{MHz}, \mathrm{CDCl}_{3}\right): \delta 7.228(\mathrm{H} 6, \mathrm{~s}), 7.290(\mathrm{OH}, \mathrm{s})$, $7.350\left(\mathrm{H}^{\prime}{ }^{\prime}, \mathrm{s}\right)$. MS [EI $70 \mathrm{eV} ; m / z(\%$ rel. int. $)$ ]: $416(17)$, 414 (51), 412 (95), 410 (100), 408 (42), 375 (11), 342 (18), 340 (27), 338 (17), 311 (20), 277 (10), 241 (18), 239 (19), 205 (14); HRMS: obs. 407.7991 , calcd. 407.8004.

2,2',3,3',4',5,5-Heptachloro-4-biphenylol (7). ${ }^{1} \mathrm{H} \quad \mathrm{NMR}$ $\left(270.13 \mathrm{MHz}, \mathrm{CDCl}_{3}\right): \delta 6.180(\mathrm{OH}, \mathrm{s}), 7.026(\mathrm{H} 6, \mathrm{~s})$, $7.351\left(\mathrm{H}^{\prime}{ }^{\prime}, \mathrm{s}\right)$. MS [EI $70 \mathrm{eV} ; m / z(\%$ rel. int. $)$ ]: $416(17)$, 414 (53), 412 (97), 410 (100), 408 (47), 342 (20), 340 (29), 338 (18), 311 (21), 276 (10), 241 (18), 239 (19); HRMS: obs. 407.8005 , calcd. 407.8004 .

$2^{\prime}, 3^{\prime}, 4,4^{\prime}, 5,5^{\prime}, 6,6^{\prime}$-Octachloro-2-biphenylol (8). Prepared from 3,4,5-trichloroanisole and pentachloroaniline as described above. ${ }^{1} \mathrm{H}$ NMR $\left(270.13 \mathrm{MHz}, \mathrm{CDCl}_{3}\right): \delta 3.000$ $(\mathrm{OH}, \mathrm{s}), 7.136(\mathrm{H} 3, \mathrm{~s})$. MS [EI $70 \mathrm{eV} ; \mathrm{m} / \mathrm{z}(\%$ rel. int. $)]$ : 450 (25), 448 (66), 446 (100), 444 (90), 410 (11), 378 (23), 376 (55), 374 (68), 372 (36), 345 (14), $311(21), 275$ (18), 239 (13); HRMS: obs. 441.7608, calcd. 441.7614.

NMR and mass spectra. ${ }^{1} \mathrm{H}$ NMR spectra for dilute $(>0.05 \mathrm{M}) \mathrm{CDCl}_{3}$ solutions were recorded on a Jeol GSX 270 FT NMR spectrometer at $270.1 \mathrm{MHz}$ in $5 \mathrm{~mm}$ diameter NMR tubes at $30^{\circ} \mathrm{C}$. The spectral width was $600 \mathrm{~Hz}$ and the number of data points $32 \mathrm{~K}$ giving a digital resolution of $0.05 \mathrm{~Hz}$. The flip angle was $90^{\circ}(8.4 \mu \mathrm{s})$, the number of scans eight and the acquisition time was 8 s. All FIDs were windowed prior to Fourier transformation (FT) by an exponential line-broadening function of the digital resolution to improve the signal/noise $(\mathrm{S} / \mathrm{N})$ ratio in the frequency spectra. All chemical shifts are referenced to the signal of $\mathrm{CDCl}_{3}(\delta=7.3$ from the internal $\left.\mathrm{Me}_{4} \mathrm{Si}\right)$. 
The ${ }^{13} \mathrm{C}$ NMR spectrum of $\mathbf{1}$, which was available in amounts of $50 \mathrm{mg}$, was recorded on a Jeol GSX 270 FT NMR spectrometer at $67.8 \mathrm{MHz}$ for $\mathrm{CDCl}_{3}$ solutions in a $5 \mathrm{~mm}$ diameter NMR tube at $30^{\circ} \mathrm{C}$. The spectral width was $7000 \mathrm{~Hz}$ and the number of data points $16 \mathrm{~K}$ giving a digital resolution of less than $1 \mathrm{~Hz}$. The flip angle was $90^{\circ}(8.8 \mu \mathrm{s})$, the number of scans 100 and the pulse repetition rate was $4 \mathrm{~s}$. The FID was windowed prior to FT by an exponential line-broadening function of the digital resolution. All chemical shifts are referenced to the signal of $\mathrm{CDCl}_{3}\left(\delta=77.0\right.$ in ${ }^{13} \mathrm{C} \mathrm{NMR}$ from the internal $\left.\mathrm{Me}_{4} \mathrm{Si}\right)$.

In the ${ }^{13} \mathrm{C}-{ }^{1} \mathrm{H}$ COSY experiment using polarization via ${ }^{1} J(\mathrm{C}, \mathrm{H})$ and ${ }^{2.3} J(\mathrm{C}, \mathrm{H})$ couplings of 1 , the ${ }^{13} \mathrm{C}$ NMR spectral parameters were the same as above except for the number of the data points, which was $2 \mathrm{~K}$ giving a digital resolution of $4 \mathrm{~Hz}$. In the ${ }^{1} \mathrm{H}$ direction the spectral width was $600 \mathrm{~Hz}$ and the number of data points $0.5 \mathrm{~K}$ giving a digital resolution of $2 \mathrm{~Hz}$, which was good enough for resolving the three-bond coupling between protons 4 and 5. The FID was windowed in both direc- tions by the exponential window functions of the digital resolutions before FT. The chemical shift scales were fixed on the signals of the one-dimensional spectra observed before.

Gas chromatography-mass spectrometry (GC-MS) was performed on a VG Auto Spec mass instrument connected to an HP 5890 gas chromatograph, which was equipped with column HP 5, $25 \mathrm{~m} \times 25 \mathrm{~mm}(0.33 \mu \mathrm{m}$ film), and using nitrogen as a carrier gas. Temperature program: $80^{\circ} \mathrm{C} ; 8^{\circ} \mathrm{C} \mathrm{min}^{-1} ; 280^{\circ} \mathrm{C}$ GC-MS(EI) was performed with an electron energy of $70 \mathrm{eV}$ for mass spectra and $36 \mathrm{eV}$ for high resolution mass spectra.

Crystal structure analysis of $\mathbf{4}$ and $\mathbf{8}$. The crystal data and experimental parameters for the data collections are given in Table 1. The lattice parameters were determined by measuring 25 reflections using Mo $\mathrm{K} \alpha(\lambda=0.7107 \AA)$ radiation at room temperature $(296 \mathrm{~K})$. Intensity data were collected on an Enraf Nonius CAD4 diffractometer using graphite monochromatized $\mathrm{MoK} \alpha$ radiation

Table 1. Experimental crystallographic data for 4 and 8.

\begin{tabular}{|c|c|c|}
\hline Compound & 4 & 8 \\
\hline Formula & $\mathrm{C}_{15} \mathrm{H}_{10} \mathrm{Cl}_{6} \mathrm{O}_{2}$ & $\mathrm{C}_{12} \mathrm{H}_{2} \mathrm{Cl}_{8} \mathrm{O}$ \\
\hline$M_{\mathrm{f}}$ & 434.94 & $445.77^{\circ}$ \\
\hline$a / \AA$ & $8.988(2)$ & $8.440(2)$ \\
\hline$b / \AA$ & $19.490(3)$ & $7.726(2)$ \\
\hline$c / \AA$ & $10.722(2)$ & $13.328(3)$ \\
\hline$x /^{\circ}$ & 90.00 & $87.64(2)$ \\
\hline$\beta /^{\circ}$ & $105.06(1)$ & $90.52(2)$ \\
\hline$y /{ }^{\circ}$ & 90.00 & $116.08(2)$ \\
\hline$V / \AA^{3}$ & $1813.8(5)$ & $780(1)$ \\
\hline$Z$ & 4 & 2 \\
\hline$d_{\text {calc }} / \mathrm{Mg} \mathrm{m}^{-3}$ & 1.593 & 1.899 \\
\hline$\mu / \mathrm{mm}^{-1}$ & 0.957 & 1.447 \\
\hline$\lambda / \operatorname{MoK} \alpha$ & 0.71073 & 0.71073 \\
\hline$F(000)$ & 872 & 436 \\
\hline Space group & $P 2{ }_{1} /{ }_{n}$ (No. 14 , non-std.) & $P-1$ (No. 2$)$ \\
\hline$T / \mathrm{K}$ & $296 \pm 1$ & $296 \pm 1$ \\
\hline Crystal size/mm & $0.20 \times 0.20 \times 0.25$ & $0.15 \times 0.20 \times 0.25$ \\
\hline Refl. for latt. meas. & 25 & 25 \\
\hline$\theta$ range for latt. meas. $/^{\circ}$ & $5-12$ & $4-14$ \\
\hline Scan method & $\omega / 2 \theta$ & $\omega / 2 \theta$ \\
\hline Scan speed $/{ }^{\circ} \min ^{-1}$ & $1-7$ & $1-7$ \\
\hline Scan width $(\omega) / /^{\circ}$ & $0.5+0.34 \tan \theta$ & $0.9+0.34 \tan \theta$ \\
\hline$\theta$ range $/{ }^{\circ}$ & $2-25$ & $2-25$ \\
\hline$h$ range & $0 \rightarrow 10$ & $0 \rightarrow 10$ \\
\hline$k$ range & $0 \rightarrow 23$ & $-9 \rightarrow 9$ \\
\hline I range & $-12 \rightarrow 12$ & $-15 \rightarrow 15$ \\
\hline Variation of std. refl. & None & None \\
\hline Refl. measured & 3523 & 2728 \\
\hline Number of unique refl. & 3192 & 2728 \\
\hline Condition of obs. refl. & $1>3.0 \sigma(I)$ & $I>3.0 \sigma(I)$ \\
\hline Refl. used in refinement & 2195 & 1551 \\
\hline Max. shift/error & $<0.01$ & $<0.01$ \\
\hline No. of parameters & 208 & 190 \\
\hline Max. in final $\Delta \rho / e \AA^{-3}$ & 0.28 & 0.70 \\
\hline$R_{\text {int }}$ & 0.026 & - \\
\hline$R^{\operatorname{int}}$ & 0.048 & 0.057 \\
\hline$R_{\mathrm{w}}$ & 0.058 & 0.072 \\
\hline Chebychev coefficients ${ }^{a}$ & $10.0,-0.786,11.1,-1.01,2.83$ & $6.56,1.11,5.05$ \\
\hline
\end{tabular}

${ }^{a} w=w^{1} \cdot\left[1.0-(\Delta F / 6 \cdot \sigma F)^{2}\right]^{2}$, where $w^{\prime}=$ Chebychev polynomial for $F_{c}$. 
$[\lambda(\operatorname{MoK} \alpha)=0.7107 \AA]$ and $\omega / 2 \theta$ scan mode. The intensity data were corrected for Lorentz and polarisation effects but not for extinction. Empirical absorption correction was done according to Walker and Stuart for both data sets, ${ }^{31}$ the maximum and minimum correction coefficients being 1.372 and 0.594 for 4 and 1.329 and 0.569 for $\mathbf{8}$, respectively. The structures were solved by direct methods using the SHELXS program. ${ }^{32}$ The final refinements were carried out by full-matrix least-squares using the CRYSTALS program, ${ }^{33}$ anisotropically for all non $\mathrm{H}$-atoms. The hydroxylic hydrogen atoms were located from the $\Delta F$ map and refined as riding atoms with fixed isotropic temperature factors $\left(U=0.08 \AA^{2}\right)$ whilst the rest of the $\mathrm{H}$-atoms were calculated to their idealized positions $(\mathrm{C}-\mathrm{H}=1.00 \AA)$ and refined as riding atoms with fixed isotropic temperature factors $\left(U=0.08 \AA^{2}\right)$. The atomic scattering factors were taken from Ref. 34 . The $F_{\text {o }}$ /parameter ratio was 10.55 for 4 and 8.16 for $\mathbf{8}$. In addition to the programs cited, the SCHAKAL program was used. ${ }^{35}$ The crystallographic calculations were performed on a micro-VAX 3100 computer at the Department of Chemistry, University of Jyväskylä.

\section{Results and discussion}

Structures of the hydroxylated chlorobiphenyls 1-8 are described in Fig. 1. The assignment of ${ }^{1} \mathrm{H}$ NMR signals is based on the characteristic intra-aromatic coupling constants, comparison between similarly substituted rings and the chemical shifts of related polychlorobiphenyls. ${ }^{18,26,36}$

In compounds 1-4 characterized by the $2^{\prime}, 4^{\prime}, 5^{\prime}-$ trichloro substitution, the ${ }^{1} \mathrm{H}$ NMR chemical shift assignment of two protons at the $3^{\prime}$ - and $6^{\prime}$-positions is not straightforward. The ${ }^{1} \mathrm{H}$ NMR chemical shifts of these two protons (recognized via their mutual five-bond coupling, $0.27-0.32 \mathrm{~Hz}$ ) stay constant within the limits of $7.405-7.398 \mathrm{ppm}(0.007 \mathrm{ppm}$ or $2 \mathrm{~Hz})$ and 7.692-7.631 $(0.061 \mathrm{ppm}$ or $16 \mathrm{~Hz})$, respectively. A natural assumption is that the chemical shift with the greater variation is associated with the proton $6^{\prime}$, which is strongly influenced by the other phenyl ring. The order of the ${ }^{1} \mathrm{H}$ NMR chemical shifts of polychlorobiphenyls containing a 2,4,5trichlorinated ring, is the opposite of that proposed for 1-4. However, the more varying chemical shift was equally associated with the proton $6^{\prime} .{ }^{18}$ In order to ascertain the NMR spectral assignments, additional experiments were carried out. Therefore, the ${ }^{13} \mathrm{C}$ NMR spectrum and two-dimensional ${ }^{13} \mathrm{C}-{ }^{1} \mathrm{H}$ COSY maps of $\mathbf{1}$ obtained by polarization transfer via ${ }^{1} J(\mathrm{C}, \mathrm{H})$ and ${ }^{2,3} J(\mathrm{C}, \mathrm{H})$ were measured.

The assignment of the ${ }^{13} \mathrm{C}$ NMR signals of 1 was based on the ${ }^{13} \mathrm{C}$ chemical shifts of the individual carbons of polychlorinated biphenyls, biphenylols and the substituent effects of the hydroxy and chlorine substituents on the biphenyl chemical shifts. ${ }^{15,19}$ The order of the chemical shifts of carbons 3 and 6 in 2,4,5-trichloro-substituted biphenyls is without exception $\delta(3)>\delta(6) .{ }^{19}$ Also, the cal-

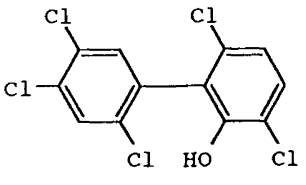

1<smiles>Oc1cc(Cl)cc(-c2cc(Cl)c(Cl)cc2Cl)c1Cl</smiles><smiles>Oc1cc(Cl)c(-c2cc(Cl)c(Cl)cc2Cl)cc1Cl</smiles><smiles>Oc1cc(Cl)c(Cl)c(Cl)c1-c1cc(Cl)c(Cl)cc1Cl</smiles><smiles>Oc1cc(Cl)c(Cl)c(Cl)c1-c1c(Cl)cc(Cl)c(Cl)c1Cl</smiles>
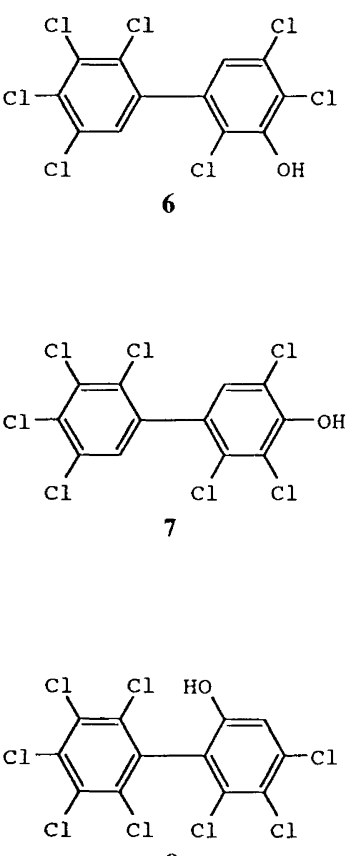

Fig. 1. Structures of compounds 1-8.

culated values according to the substituent effects are in agreement with the assignment.

The ${ }^{13} \mathrm{C}-{ }^{1} \mathrm{H}$ COSY contour maps of 1 unambiguously reveal that the order of the chemical shifts for the protons $\mathrm{H} 3^{\prime}$ and $\mathrm{H}^{\prime}{ }^{\prime}$ and the carbons $3^{\prime}$ and $6^{\prime}$ are reversed. Thus, if the order of ${ }^{1} \mathbf{H}$ NMR chemical shifts in the $2^{\prime}, 4^{\prime}, 5^{\prime}$-trichloro substituted ring in compounds $\mathbf{1 - 4}$ is $\delta\left(\mathrm{H}^{\prime}{ }^{\prime}\right)<\delta\left(\mathrm{H}^{\prime}\right)$ as deduced above, the ${ }^{13} \mathrm{C}$ NMR chemical shift order of the carbons $3^{\prime}$ and $6^{\prime}$ is $\delta\left(C-6^{\prime}\right)<\delta(\mathrm{C}$ $\left.3^{\prime}\right)$ in compounds 1-4; the same as in the corresponding polychlorobiphenyls. ${ }^{19}$

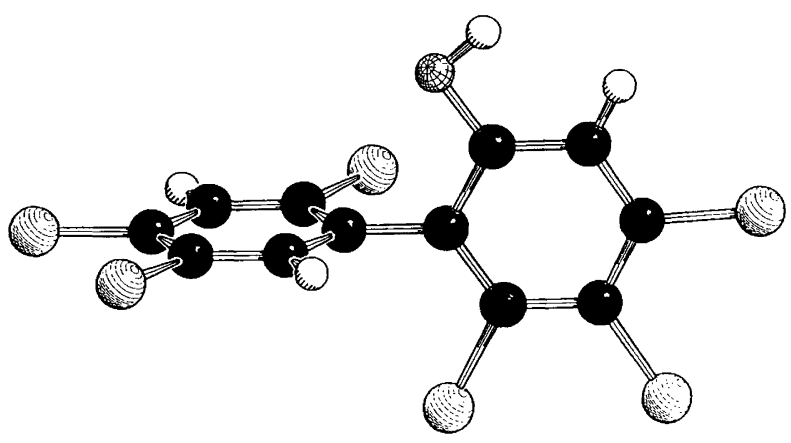

Fig. 2. A SCHAKAL plot $^{35}$ for compound 4. 


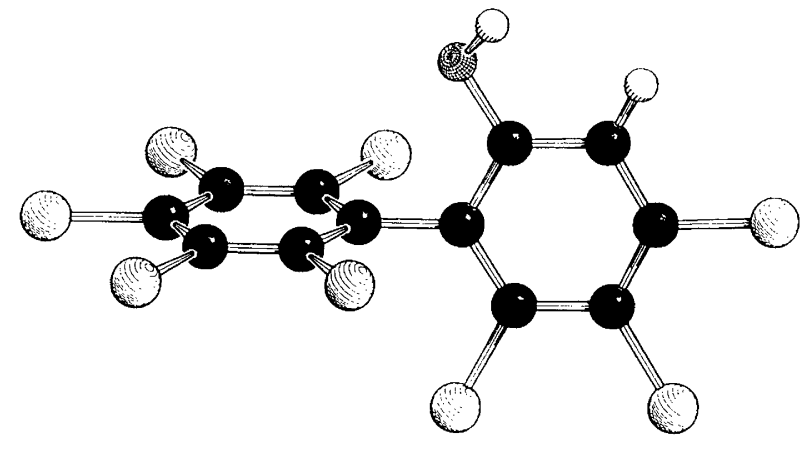

Fig. 3. A SCHAKAL plot $^{35}$ for compound 8.

A view of the molecules $\mathbf{4}$ and $\mathbf{8}$ is presented in Figs. 2 and 3 , respectively. The bond distances and angles for compounds $\mathbf{4}$ and $\mathbf{8}$ show no abnormal values. The torsion angles between the benzene rings have values $90.2(4)^{\circ}$ and $83.5(6)^{\circ}$ for compounds 4 and 8, respectively. The torsion angles observed are quite close to the values found in di- and tri-ortho-substituted polychlorobiphenyls, $75.35(9)^{\circ} \quad\left[2,2^{\prime}, 3,4^{\prime}, 5^{\prime}\right.$-pentachloro-4-methoxybiphenyl $]^{3-}$ and $82.7(1)^{=}\left[2,2^{\prime}, 4,4^{\prime}, 5^{\prime}, 6\right.$-hexachloro-3methoxybiphenyl], ${ }^{38}$ but larger than in a mono-orthosubstituted polychlorobiphenyl, $58.2^{\circ}, \quad\left[2,3,3^{\prime}, 4,5^{\prime}\right.$ pentachlorobiphenyl]. ${ }^{39}$

The mass spectral parameters do not always distinguish between the isomers, as they have done in the cases of methoxychlorobiphenyls. ${ }^{25,40}$ However, the mass spectra of 1-8 gave the molecular ion and the isotopic clusters gave the number of chlorine substituents. High resolution mass spectra were recorded to obtain the exact relative molecular masses of $\mathbf{1 - 8}$.

Acknowledgements. Mr. R. Kauppinen is gratefully acknowledged for his help in running some NMR spectra and Ms. M. Lahtiperä for running the mass spectra.

\section{References}

1. Kannan, N., Tanabe, S., Tatsukawa, R. Arch. Environ. Health 43 (1988) 11.

2. Hutzinger, O., Jamieson, W. D., Safe, S., Paulman, L. and Ammon, R. Nature (London) 252 (1974) 698.

3. Safe, S., Jones, D. and Hutzinger, O. J. Chem. Soc., Perkin Trans. 1 (1976) 357.

4. Kato, S. J., McKinney, J. D. and Mathew's, R. Toxicol. Appl. Pharmacol. 53 (1980) 389.

5. Schnellmann, R. G., Putnam, C. W. and Sipes, I. G. Biochem. Pharmacol. 32 (1983) 3233.

6. Yoshimura, H., Yonemoto, Y., Yamada, H., Koga, N., Oguki, K. and Saeki. S. Xenobiotica 17 (1987) 897.

7. Koga, N., Beppu, M., Ishida, C. and Yoshimura, H. Xenobiotica 19 (1989) 1307.

8. Klasson-Wehler, E., Bergman, A.. Brandt, I., Darnerud, P. O. and Wachtmeister, C. A. Drug Metab. Disp. 17 (1988) 441.

9. Klasson-Wehler, E., Jonsson, J., Bergman, A.., Brandt, I. and Darnerud, P. O. Chemosphere 19 (1989) 809.
10. Klasson-Wehler, E., Brunström, B., Bannung, U. and Bergman, Å. Chem.-Biol. Interact. 73 (1990) 121.

11. Paasivirta, J., Tarhanen, J. and Soikkeli, J. Chemosphere 15 (1986) 1429.

12. Kuroki, H., Haraguchi, K., Saito, H., Masuda, Y., KlassonWehler, E. and Bergman, A. Fukuoka Igaku Zasshi 84 (1993) 236.

13. Paasivirta, J., Herzschuh, R., Humppi, T., Kantolahti, E., Knuutinen, J., Lahtiperä, M., Laitinen, R., Salovaara, J., Tarhanen, J. and Virkki, L. Environ. Health Perspect. 60 (1985) 269.

14. Ariyoshi, N., Koga, N., Oguri, K. and Yoshimura, H. Xenobiotica 22 (1992) 1275 .

15. Lötjönen, S. and Äyräs, P. Finn. Chem. Lett. (1978) 260

16. Poso, A., Tuppurainen, K., Ruuskanen, J. and Gynther, J. J. Mol. Struct. (Theochem.) 282 (1993) 259.

17. Waller, C. L. and McKinney, J. D. J. Med. Chem. 35 (1992) 3660.

18. Yanagisawa, M., Hayamizu, K. and Yamamoto, O. Magn. Reson. Chem. 24 (1987) 184.

19. Yanagisawa, M., Hayamizu, K. and Yamamoto, O. Magn. Reson. Chem. 24 (1986) 1013.

20. Sinkkonen, S., Kolehmainen, E. and Koistinen, J. Int. J. Environ. Anal. Chem. 47 (1993) 7.

21. Sinkkonen, S., Kolehmainen, E., Laihia, K., Koistinen, J. and Rantio, T. Environ. Sci. Technol. 27 (1993) 1319.

22. Safe, S., Bandiera, S., Sawyer, T., Robertson, L., Safe, L., Parkinson. A.. Thomas. P. E., Ryan. D. E.. Reik. L. M.. Levin. W.. Denomme, M. A. and Fujita, T. Envirom. Health Perspect. 60 (1985) 47.

23. Cadogan, J. I. G. J. Chem. Soc. (1962) 4257.

24. Sundström, G. Acta Chem. Scand. 27 (1973) 600.

25. Jansson, B. and Sundström, G. Biomed. Mass. Spectrom. I (1974) 386.

26. Mullin, M. D., Plochini, C. M., McCrindle, S., Romkes, M., Safe, S. H. and Safe, L. M. Environ. Sci. Technol. 18 (1984) 468.

27. Darnerud, P. O., Brandt, I., Klasson-Wehler, E., Bergman, A., D'Argy, R., Dencker, L. and Sperber, G. R. Xenobiotica 16 (1984) 295.

28. Bergman, A., Nilsson, A., Riego, J. and Örn, U. Acta Chem. Scand. 44 (1990) 1071.

29. Haraguchi, K. and Bergman, A. Chemosphere 23 (1991) 1837.

30. Mannila, E. Chemosphere 25 (1992) 271.

31. Walker, N. and Stuart, D. Acta Cristallogr., Sect. A 39 (1983) 158.

32. Sheldrick, G. M. In: Sheldrick, G. M., Kruger, C. and Goddard, R., Eds., Crystallographic Computing 3, Oxford University Press, Oxford 1985, 175.

33. Watkin, D., Carruthers, J. R. and Betteridge, P. W. CRYSTALS, Chemical Crystallography Laboratory, Oxford, England 1990.

34. International Tables for X-Ray Crystallography, Kynoch Press, Birmingham 1974, Vol. IV.

35. Keller, E. SCHAKAL88/V16, Kristallographisches Institut der Universität Freiburg, Germany.

36. Breitmaier, E. and Voelter, W. Carbon-13 NMR Spectros'cop!, 3rd ed., completely revised version, $\mathrm{VCH}$, Weinheim, Germany 1987, p. 256.

37. Rissanen, K., Valkonen, J. and Mannila, B. Acta Crystallogr., Sect. C 44 (1988) 682.

38. Rissanen, K., Valkonen, J. and Mannila, B. Acta Crystallogr., Sect. C 44 (1988) 684.

39. Mannila, E. and Rissanen, K. Acta Chem. Scand. 48 (1994) In press.

40. Tulp, M. Th. M., Olie, K. and Hutzinger, O. Biomed. Mass. Spectrom. 4 (1977) 310.

Received February 21, 1994. 